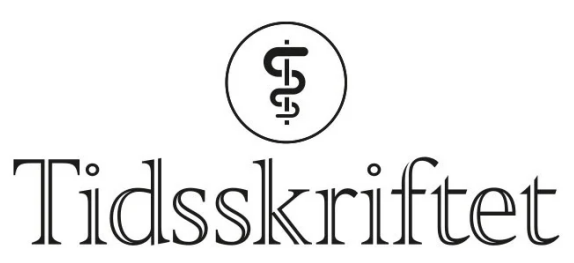

DEN NORSKE LEGEFORENING

\title{
Vitamin D og covid-19
}

\author{
DEBATT
}

GUNNAR HASLE

hasle@reiseklinikken.com

Gunnar Hasle er spesialist i infeksjonssykdommer med doktorgrad i skjæringspunktet mellom medisin og zoologi. Siden 1999 har han drevet Reiseklinikken i Oslo.

Forfatter har fylt ut ICMJE-skjemaet og oppgir ingen interessekonflikter

\section{Så langt har ingen funnet en medisin som dramatisk bedrer utsiktene ved alvorlig SARS-CoV-2-infeksjon, og det er ennå et stykke igjen til at vaksiner kan bli allment tilgjengelige. Kan befolkningens D-vitaminstatus ha betydning for effektiv behandling og forebygging av infeksjoner?}

Vitamin D synes å spille en viktig rolle i immunforsvaret. En metaanalyse fra BMJ i 2017 konkluderte med at tilskudd av vitamin D ga en generell beskyttelse mot luftveisinfeksjoner, og effekten var størst hos dem som hadde vitamin D-mangel (1) . Vi ser at mange av risikofaktorene for covid-19 (overvekt, høy alder og sterkt pigmentert hud) faller sammen med risiko for vitamin D-mangel (므). Det er i den sammenheng tankevekkende at afroamerikanere har høy risiko for å dø av covid-19 i forhold til hvite (3), samtidig som covid-19 ikke synes å ramme Afrika særlig hardt (4.). I Afrika vil aldersfordelingen kunne forklare mye, men vitamin D fra sollyset kan være medvirkende.

Data er foreløpig sparsomme, men observasjonsstudier peker i retning av at lavt nivå av vitamin D øker risikoen for å få covid-19 (므). En nypublisert studie sammenlignet tilgjengelige data for D-vitamin i blodet i forskjellige land mot insidens og dødelighet av covid-19 (5). Analysen indikerte at høyere nivå av D-vitamin i blodet i befolkningen ga lavere insidens av covid-19, men det var ikke nok evidens til å kunne konkludere med om det var en assosiasjon mellom vitamin D-nivåer og alvorlighetsgrad og mortalitet av covid19. Det trengs kontrollerte studier for å finne ut om tilskudd av D-vitamin har en profylaktisk effekt mot covid-19.

«Det trengs kontrollerte studier for å finne ut om tilskudd av D-vitamin har en profylaktisk effekt mot covid-19" 
Man kunne også tenke seg at tilskudd av vitamin D kan brukes i behandlingen av covid-19. I en spansk pilotstudie inkluderte man sykehusinnlagte pasienter som fikk klorokin og azitromycin (som senere har vist seg ikke å ha noen effekt på covid-19) og randomiserte dem for tilskudd av D-vitaminkapsler ( $266 \mu \mathrm{g}$ ). Behandlingsgruppen (5o pasienter) fikk to kapsler første dag, én kapsel dag 3, 5 og 7, deretter ukentlig(므). De 26 kontrollpasientene fikk ingen placebo. Bare én av de 50 som fikk D-vitamin trengte intensivbehandling, og ingen av dem døde, mens 13 i kontrollgruppen trengte intensivbehandling og to døde $(\mathrm{p}<$ o,oo1). Det blir interessant å se om funnene kan reproduseres i randomiserte, placebokontrollerte kliniske fors $ø$ k. Ifølge forfatterne er en stor multisenterstudie med vitamin D-tilskudd på gang i Spania nå.

«Det er altså, uavhengig av covid-19, på sin plass å anbefale en skje tran hver dag»

Et nærliggende spørsmål er: Bør alle ta tran? En ekspertgruppe for vitamin D, oppnevnt av Nordisk ministerråd, anbefalte i 2014 at nivået bør ligge over 50 nmol/L (7.). Vi har ikke sikre data på hvor høyt vitamin D-nivået ligger i den norske befolkningen, men en studie fra 2010 viste at gjennomsnittsverdien hos ikke-røykere lå på litt over $50 \mathrm{nmol} / \mathrm{L}$ og lavere i vintermånedene (모). Tilskudd av vitamin D er en enkel, ufarlig og billig intervensjon, som selvfølgelig ikke gjør andre tiltak mot covid-19 overflødige. Ekspertgruppen anbefalte et inntak på $10 \mu \mathrm{g} / \mathrm{dag}$, og $20 \mu \mathrm{g} / \mathrm{dag}$ for eldre. Det er altså, uavhengig av covid-19, på sin plass å anbefale en skje tran $(10 \mu \mathrm{g} / 5 \mathrm{~mL})$ hver dag, eller tilsvarende, nå som vi går inn i en årstid med mindre sollys.

\section{LITTERATUR}

1. Martineau AR, Jolliffe DA, Hooper RL et al. Vitamin D supplementation to prevent acute respiratory tract infections: systematic review and meta-analysis of individual participant data. BMJ 2017;356: i6583. [PubMed][CrossRef]

2. Martineau AR, Forouhi NG. Vitamin D for COVID-19: a case to answer? Lancet Diabetes Endocrinol 2020; 8: 735-6. [PubMed][CrossRef]

3. Price-Haywood EG, Burton J, Fort D et al. Hospitalization and mortality among black patients and white patients with Covid-19. N Engl J Med 2020;382: 2534-43. [PubMed][CrossRef]

4. Worldometer. https://www.worldometers.info/coronavirus/ Lest 9.10.2020.

5. Ali N. Role of vitamin D in preventing of COVID-19 infection, progression and severity. J Infect Public Health 2020; 13: 1373-80. [PubMed][CrossRef]

6. Entrenas Castillo M, Entrenas Costa LM, Vaquero Barrios JM et al. "Effect of calcifediol treatment and best available therapy versus best available therapy on intensive care unit admission and mortality among patients hospitalized for COVID-19: A pilot randomized clinical study". J Steroid Biochem Mol Biol 2020; 203: 105751. [PubMed][CrossRef]

7. Brustad M, Meyer HE. Vitamin D-hvor mye er nok, og er mer bedre for helsen? Tidsskr Nor Legeforen 2014; 134: 726-8. [PubMed][CrossRef]

8. Grimnes G, Almaas B, Eggen AE et al. Effect of smoking on the serum levels of 25-hydroxyvitamin D depends on the assay employed. Eur J Endocrinol 2010; 163:339-48. [PubMed][CrossRef]

Publisert: 9. november 2020. Tidsskr Nor Legeforen. DOI: 10.4045/tidsskr.20.o8o3

Mottatt 7.10.2020, godkjent 14.10.2020.

(C) Tidsskrift for Den norske legeforening 2023. Lastet ned fra tidsskriftet.no 26. april 2023. 